\title{
TE ELFDER URE
}

\section{Van een Aardbeving en een Loterijbriefje}

DOOR

\author{
SIR REGINALD ST.-JOHNSTON ${ }^{\mathbf{1}}$ ) \\ Vertaald door J. Heyligers
}

Toen de in de blakerende zon liggende landweg Naomi op den top van den heuvel gebracht had, aan welks voet haar huisje te zien was, hield zij stil, nam de mand met fruit van het hoofd en tuurde ingespannen over het juist afgelegde pad, dat verweg door bruin-groene katoenvelden voerde, voor welker produkt het eiland St. Vincent terecht beroemd is.

Wel deed het zien van haar zuster met de kinderen op den drempel van het huis haar even glimlachen, maar lang bleef die lach niet, want een droevige trek kwam er weldra voor in de plaats, een trek, die den laatsten tijd helaas maar al te dikwijls voor den dag kwam.

Naomi had zorgen. Inderdaad, het werd haar bijna te zwaar, maar gelukkig gaf een onverzettelijke wilskracht gepaard aan een degelijk karakter haar sterkte bij allen tegenspoed en kon haar opgewekt doen doorgaan.

Daar in die kleine vallei in een met palmbladeren gedekt huisje lag haar man, kreupel sinds een ongeluk, dat hun ruim vijf en twintig jaar geleden overkomen was, en nu begon de moed haar langzaam aan te ontzinken. De purper getinte heuvels in de verte gaven de zuidgrens aan van den beruchten Mount Soufrière, wiens vreeselijke uitbarsting nu meer dan een kwart eeuw geleden niet alleen het geheele eiland St. Vincent in alle richtingen deed sidderen maar ook, overdrachtelijk gesproken, de geheele wereld had doen trillen, een wereld, die verstomd stond toen langzamerhand meerdere bijzonderheden bekend raakten. In hun klein eiland waren verspreide nederzettingen, ja geheele dorpen weggevaagd - tweeduizend menschen in een enkel oogenblik gedood

1) Zie „De West-Indische Gids” van November 1932. 
en ontelbare anderen verminkt, velen verloren al wat zij bezaten.

Nooit zou zij dien verschrikkelijken dag kunnen vergeten, toen het heele eiland als een woelige zee begon te golven en plotseling vlammen en rook door den Soufrière uitgebraakt werden, na een honderd jaar van volkomen rust; asch, witgloeiende steenen en gesmolten lava regenden neer op het dorpje Richmond, waar zij woonden. Door een panische schrik bevangen, waren zij dwars over het land weggehold, weg van die levende hel, die hen vervolgde. Eerst werd hun eenig kind gedood door een enormen steen die uit de dreigende duisternis van dien vreeselijken middag op hen neerviel; en toen, juist bij het bereiken van de kust en de betrekkelijke veiligheid van de zee, kwam een kleinere steen, een uit een hagelbui van keien rondom hun neerratelend, op haar man terecht en trof hem op de ruggegraat net toen hij voorover boog om de kano af te duwen.

Hoe het haar lukte om er hem in te tillen en daarna uit het onmiddellijke gevaar weg te komen is iets, dat zij zich niet kan herinneren.

Maar op de een of andere wijze was zij er in geslaagd, door instinct geleid, door de duisternis dat tooneel van verschrikking te ontvluchten. $\mathrm{Al}$ wat zij zich later herinnerde, was dat een reddingsploeg, die uit een grooter vaartuig over hen heenboog, haar in nagenoeg bewusteloozen toestand had aangetroffen. Daar had men op het eerste oogenblik gedacht, dat de man, roerloos op den bodem van de kano uitgestrekt, dood was; heel langzaam aan herstelde hij want al moest hij de rest van zijn dagen op krukken gaan, de levensdraad zelf was niet afgesneden.

Wel konden de autoriteiten door het Mansion House Fonds daartoe in staat gesteld, haar een tegemoetkoming verstrekken, maar er waren duizende gezinnen, die ondersteuning noodig hadden en de wekelijksche uitkeering van een shilling of zoo was ternauwernood voldoende voor het weinigje voedsel, dat hij noodig had. Maar met een kloek besluit nam zij haar last op en door hard werken, volhouden en een helder inzicht, was zij er langzamerhand in geslaagd een stuk grond te kunnen pachten en kon zij op een klein succes bogen.

Een paar jaar geleden echter, was haar gebrekkige zuster door haar man verlaten, een nietsdoener verleid door valsche voorspiegelingen over Cuba. Die liet haar met twee zuigelingen achter en dus viel aan Naomi de taak ten deel nog een invalide en twee hulpelooze kinderen te onderhouden. Gewillig had zij hen opgenomen ofschoon zij wel degelijk begreep wat zij begonnen was. 
Het beteekende meer monden voeden, maar door het voortduren van haar voorspoed kon ze die meerdere kosten over het hoofd zien. Doch de laatste twee jaar hadden een scherpen val in de marktprijzen van arrow-root en Sea-Island-katoen te zien gegeven, de twee voornaamste producten van St. Vincent, en haar toch al kleine oogsten daarvan bleken vrijwel onverkoopbaar.

Inderdaad ging het geld steeds de deur uit en niets kwam er meer binnen zoodat zij genoodzaakt was haar paar acres land aan den winkelier Stewart te verpanden voor de over een langen tijd van hem betrokken goederen. En tot overmaat van ramp was zij vandaag, op weg om den dokter te halen omdat haar man weer een van zijn aanvallen van pijn had, meneer Stewart tegengekomen, die haar verteld had dat alles verkocht zou worden als zij niet binnen een week de zaken in het reine kon brengen.

Daar stond zij nu als een moderne, vrouwelijke Job; letterlijk alles liep haar tegen en toch trachtte zij opgewekt te zijn. En nu was die mand met aanlokkelijk, helder rood fruit, dat zoo aardig harmonieerde met d'r bruine hoofddoek en blauwe rok, onverkocht teruggekomen. Terwijl zij daar ingespannen den weg afkeek, dien ze juist afgelegd had, hopend in de verte den dokter op z'n welbekend schimmeltje te zien aankomen, vroeg zij zich niet alleen af, hoe ze aan het geld voor dit doktersbezoek zou komen, maar zelfs aan de paar stuivers voor den volgenden maaltijd.

De zaken gingen tegenwoordig slechter en slechter. Wel, het was nog geen maand geleden, vóór dat alle koopers in St. Vincent besloten om met het oog op de tijden voorloopig geen katoen meer in te koopen, dat zij ten minste van de gewone levensbehoeften zeker was, ja zelfs misschien van een extra'tje bij een bijzondere gelegenheid.

Toen had zij eens een eigenaardige ondervinding gehad. $\mathrm{Zij}$ was namelijk op een dag naar Georgetown geweest om er inkoopen te doen en had er toen den ouden Williams ontmoet, die een winkel in alles en nog wat dreef en die haar uit de grap voorgesteld had een briefje in de inter-insulaire sweepstake te nemen. Deze werd elk jaar in elkaar gezet met het oog op de groote gebeurtenis van de jaarlijksche wedrennen, die in de volgende maand gehouden zouden worden.

„Waarom zou ik nu een lot koopen, meneer William", zei ze lachend. „In die dingen heb ik nog nooit geluk gehad. Ja, verleden jaar heeft Matthew Clarke, de schoolmeester, tien pond gewonnen, maar dat is dan ook de eenige persoon, dien ik ken, die ooit iets gewonnen heeft. Bijna altijd gaat het geld naar de andere eilanden". 
„Kijk, Naomi”, antwoordde de winkelier lachend, „ik heb nog maar drie briefjes en als je er wat geld voor over hebt, dan kun je een massa geld winnen. Men denkt, dat de groote prijs dit jaar driehonderd pond zal zijn! Maar er zeker van zijn kan men nooit en als je toch al weinig geluk hebt, is het misschien beter niet mede te doen".

Maar naar huis terugwandelend begon zij een beetje spijt te krijgen het niet geprobeerd te hebben. Als zij nu maar 's een aanwijzing kreeg wat een goed nummer zou zijn om te kiezen!

Terwijl zij zoo naar huis wandelde en hardop in zichzelf hierover praatte, in die grappige zelf-conversatie die zoo dikwijls onder de negers voorkomt, vlogen er uit een veld aan haar rechterhand drie kraanvogels op. Dat deed haar even opschrikken en „drie" mompelend stond zij met open mond even stil zich met verwondering afvragend of dat een door den Hemel gegeven teeken was, net als een oude Romein in een geheel ander deel van de wereld dat tweeduizend jaar geleden gedaan zou hebben.

$\mathrm{Zij}$ was nog niet zoo veel verder of ze zag, ook al weer rechts, drie hooge palmboomen net als vingers, die omhoog steken. Natuurlijk had zij daar al honderde keeren langs geloopen, maar op zoo'n manier had hun bijzondere beteekenis zich tot nu toe nog nooit aan haar doen gevoelen. Het drong niet tot haar door, dat zij nu naar teekens aan het uitkijken was en dat als zij maar goed genoeg overal er naar uitkeek zij ze overal zou vinden.

„God”, riep ze vol ontzag uit. „Dat is nu al twee keer, dat ik dit getal zie. Ik geloof werkelijk, dat het de bedoeling is mij een teeken te geven. Naomi als je nou koppig bent ga je een massa geld verliezen". Het werd al donker en ze versnelde haar tred terwijl zij in zich zelf een psalm zong om de booze geesten van zich af te houden, die haar zouden willen belagen. Plotseling, juist toen ze een hoek wilde omslaan, sprong er iets op den weg voor haar liggend op en verdween met vaart in het kreupelhout aan haar rechterhand. Het was maar een geit, maar het was voldoende om haar vreeselijk te doen schrikken.

"Ie-ee", schreeuwde ze 't uit en de mand met inkoopen op haar hoofd schoof op zij en nog net kon ze die met ééne hand grijpen. $\mathrm{Zij}$ kon echter niet verhinderen dat er drie kleine pakjes uitrolden voor dat ze tijd had de mand goed recht te zetten; en daar lagen ze nu op een rijtje op den weg vlak vóór haar.

Met een wild kloppend hart stond zij ze even aan te staren en met de mand nog op het hoofd hurkte zij neer om die langzaam op te rapen en één voor één weer in de mand te leggen terwijl ze met 
nadruk tot zichzelf zei: „Nou is het genoeg. Jij gaat morgenochtend direct naar meneer William en je koopt daar ticket nummer drie".

Maar wat haar daarop ineens aan den rand van de wanhoop bracht, was de invallende gedachte, dat uit die duizende loterijbriefjes nummer drie al lang geleden verkocht moest zijn. Wat niet weg nam dat zij den volgenden morgen heel vroeg op pad ging om meneer Williams te vragen haar eens de nog over zijnde tickets te laten zien.

3001,3002 en 3003 waren de eenige nummers.

„Die moet ik hebben”, zei ze heel beslist op het laatste wijzende.

Dat was een maand geleden gebeurd en op weg naar huis had zij het briefje zorgvuldig tusschen de bladen opgeborgen van een ouden geillustreerden prijscourant, die op de een of andere manier van een groot Amerikaansch warenhuis naar dit afgelegen punt was verdwaald; door de moeilijkheden van den laatsten tijd was haar dat door het hoofd gegaan.

De ziekte van haar man had haar ernstig bezorgd gemaakt. Zooals het gewoonlijk met chronische invaliden gaat, was hij wel eens knorrig, zoodra hij zich wat minder gevoelde en hoewel opgewekt genoeg zoolang hij zich op z'n krukken vrijelijk kon bewegen verbeeldde hij zich toch allerlei plijnen te hebben als hij eens voor een dag of twee binnenshuis moest blijven. En vandaag had hij haar zóó aan het schrikken gebracht dat zij haastig was weggehold om den dokter te halen en nu stond zij daar ingespannen te turen of ze hem in de verte zag aankomen.

Toen het schimmeltje met den dokter in het zicht kwam, ging zij naar huis om haar man van de aankomst te vertellen.

„Maar ik ben al weer beter, Naomi”, antwoordde hij grommig „en daar heb je nu den dokter gehaald, dat is toch geld weggooien voor niks".

Zij beet zich op de lip en stond op het punt er hem een verwijt van te maken dat hij zoo gauw al weer veranderde sinds hij van morgen om hulp riep, toen haar beter gevoel de overhand kreeg en zij hem met een paar vriendelijke woorden suste, waarop zij begon het hutje zoo goed mogelijk netjes te maken.

De kinderen waren in een stukje tuin voor de hut aan het spelen en - zooals kinderen over heel de wereld doen - bouwden ze een huis. Voor de muren hadden zij houtjes in den grond gestoken en voor de voordeur kwam een reepje blik goed van pas, terwijl 
de Amerikaansche catalogus als het eenige platte, stijve ding, dat zij konden vinden, voor het dak als aangewezen was. Die was een paar keer gevallen en stukjes papier waren er uit weggewaaid, wat hen minder deerde.

Zoodra de dokter aankwam ging hij opgewekt naar binnen naar den zieke, maar vond spoedig dat er niets ernstigs aan de hand was. Hij had met Naomi te doen, die hij sinds lang kende en wier flinkheid hij steeds bewonderde, en hield nu even op om met haar een praatje te maken.

„Wil je de krant van vandaag eens lezen?” vroeg hij, terwijl hij die uit zijn zak haalde. „Iemand schrijft over de groote uitbarsting en ik geloof, dat hij op een bepaald punt jelui op het oog heeft. Ik denk wel dat je het aardig zult vinden ook al als ik me daarin vergis." Zoo pratende, wuifde hij een vroolijk goeden-dag toe, gaf nog wat aanwijzingen voor den patient en stapte, na de kinderen over het hoofd gestreken te hebben weer te paard om zijn ronde verder te vervolgen, want voor dit district was z'n auto van geen nut.

Naomi begon met haar zuster het middagmaal klaar te maken en toen hun potje op het vuur stond greep zij haar krant, want al had zij het nu erg armelijk, de gouvernementsschool had ze met vrucht gevolgd.

Maar voordat zij nog iets over de aardbeving had kunnen vinden trok de groote kop van een artikel haar volle aandacht. Die maakte den uitslag bekend van de groote race van gisteren en vermeldde met voldoening dat het winnende nummer in de sweepstake nu eens in St. Vincent gevallen was. „Wij kunnen nog niet mededeelen wie de gelukkige houder is van ticket no. 3003, maar wij meenen dat deze verkocht is uit een boek aan den heer Williams, een winkelier in Georgetown, afgegeven".

Haar handen beefden zoodat de krant haar uit de vingers gleed en door de open staande deur riep zij naar binnen: „Groote God, Joe, ik heb den hoofdprijs!'

„Wat ben je nou aan het kletsen?" riep een twistzieke stem van een bed in een donkeren hoek. „Wanneer zal mijn eten klaar zijn? Ik lig al zoo lang te wachten met je geteut".

„De prijs, Joe, de prijs!” was al, wat ze kon uitbrengen terwijl zij naar binnen vloog om den catalogus te zoeken.

Zenuwachtig zocht zij op alle mogelijke plaatsen en rende toen weer naar buiten om haar zuster te vragen waar die was. En op eens, met een zucht van verlichting, zag ze hem op den grond liggen, bij de kinderen. Den prijscourant te grijpen en dien vlug door 
te loopen was natuurlijk het werk van een oogenblik, maar hoe zij ook zocht, van het loterijbriefje was geen spoor te bekennen.

„Joe, Clara”, riep zij angstig uit, „Hebben jelui niet die ticket uit dit boek gehaald, die ik er in opgeborgen had?"

„Nee, zeker niet”, riepen die twee tegelijkertijd uit toen het tot hen doordrong wat al dat gezoek beteekende. "Je wilt toch niet zeggen, dat je wat geld gewonnen hebt?"

„Geld?” riep zij als waanzinnig uit. „Ik zeg je dat ik den hoofdprijs gewonnen heb en nu kan ik de ticket niet vinden". Thans kon zij zich niet langer inhouden en begon als een kind te schreien, terwijl ze met de armen van opwinding om zich heen sloeg.

Terwijl de kreupele eentonig aan het weeklagen was gingen de twee vrouwen maar weer opnieuw aan het zoeken. $\mathrm{Zij}$ ondervroegen de kinderen, die niets nieuws konden vertellen, snuffelden overal en overal maar alles was te vergeefs. Eindelijk, doodmoe, besloot Naomi om wat thee te gaan maken voor den tot nu toe verwaarloosden maaltijd. $\mathrm{Zij}$ nam een emmer en ging naar de put vlakbij om wat water te putten en juist zou zij het touw laten zakken toen een wit stukje papier, dat door den wind tegen het bovenste deel van den putmuur geblazen was, haar in het oog viel. Snakkend naar adem boog zij zich voorover om het te grijpen, waarbij het touw haar uit de hand schoot en met den emmer in de diepte verdween.

"Mijn ticket”, schreeuwde zij met wijd-open oogen en ze holde zoo hard als ze maar kon naar huis, steeds schreeuwend „Ik heb 'm gevonden, Ik heb 'm gevonden!'

Er is weinig meer te zeggen. Naomi's prijs was $£ 316$, voldoende om al haar schulden af te betalen en nog een aardig sommetje over te houden om de moeilijke tijden door te komen. Aan ieder, die het maar hooren wil, vertelt zij nu dat haar beschermengel haar in de keus van het briefje geholpen heeft, maar hoe zij het zal kunnen klaarspelen uit te leggen hoe het komt dat de onfortuinlijke houder van het werkelijke nr. 3 niet de winnaar is, ben ik niet bij machte te zeggen. 